\title{
Current status of wilt/root rot diseases in major chickpea growing areas of Ethiopia
}

\section{Tebkew Damte \& Chris O. Ojiewo}

To cite this article: Tebkew Damte \& Chris O. Ojiewo (2016): Current status of wilt/root rot diseases in major chickpea growing areas of Ethiopia, Archives of Phytopathology and Plant Protection

To link to this article: http://dx.doi.org/10.1080/03235408.2016.1180925

曲 Published online: 20 May 2016.

Submit your article to this journal

Q View related articles $\longleftarrow$

View Crossmark data 


\title{
Current status of wilt/root rot diseases in major chickpea growing areas of Ethiopia
}

\author{
Tebkew Damte ${ }^{\mathrm{a}}$ and Chris O. Ojiewo ${ }^{\mathrm{b}}$ (D)
}

aDebre Zeit Agricultural Research Center, Pulses, Oil Fibre Crops Research Team, Ethiopian Institute of Agricultural Research, Debre Zeit, Ethiopia; ' International Crops Research Institute for the Semi-Arid Tropics (ICRISAT) - Ethiopia, Eastern and Southern Africa Research Program, Addis Ababa, Ethiopia

\begin{abstract}
Wilt/root rot diseases are a major chickpea production constraint in Ethiopia causing yield losses by reducing the number of plants. To determine the current status of disease incidence and distribution, surveys were conducted in the 2013/2014 and 2014/2015 cropping seasons in major chickpea growing zones of Ethiopia. Despite recent efforts in dissemination of improved varieties, low to high incidence of $0.0-83.4,0.0-27.6,1.3-19.8$ and $0.0-16.3 \%$ and $1.0-81.9$, 0.0-25.5, 3.0-13.9 and 1.0-21.5\% in East Gojjam, Southwest Shewa, North Shewa and West Shewa in 2013/2014 and 2014/2015, respectively. Therefore, integrated pest management strategies should be developed and availed to farmers.
\end{abstract}

\section{ARTICLE HISTORY}

Received 5 January 2016

Accepted 8 April 2016

\section{KEYWORDS}

Chickpea; Cicer arietinum; wilt/root rot; Fusarium oxysporum fs ciceri; Ethiopia

\section{Introduction}

Ethiopia is the largest producer, consumer and exporter of chickpea in Africa and shares some $4.5 \%$ of global chickpea market and more than $60 \%$ of Africa's global chickpea market. In the past one decade, the area under chickpea cultivation has increased by $43 \%$ from 167,569 ha in 2005 to 239,755 ha in 2015 while yields increased from $964 \mathrm{~kg} / \mathrm{ha}$ to $1913 \mathrm{~kg} / \mathrm{ha}(98 \%)$. These changes are part of the outcomes of research and dissemination of chickpea production technologies. Chickpea in Ethiopia is grown in Woina Dega (midlands to high altitude with altitudes between 1500 and $2600 \mathrm{~m}$ above mean sea level) agroecologies with a rainfall of 700-1300 mm. It is mostly adapted to cool and moderate temperature regimes during the growing period.

The largest growing regions are Oromiya (West, East, and North West Shoa and Arsi zones), Amhara (South Gonder, North and South Wollo and North Shoa 
zones) and few districts of Tigray and SNNP (Southern Nations, Nationalities and Peoples) regions. In the 2014/2015 season, 1,081,755 households produced 458,682 tonnes of chickpea of which $80 \%$ was consumed domestically and the remaining 20\% was exported to markets in different countries (CSA 2015). The Amhara and Oromiya regional states together accounted for 91.6, 94.9 and 96.3\% the households, total area and the total chickpea production, respectively. While the current national average yield is $1913 \mathrm{~kg} / \mathrm{ha}$, the average yields in Ahmara and Oromia Regions are 1809 and 2087 kg/ha, respectively.

In Ethiopia, chickpea is mostly produced by smallholder farmers either as sole or double crop with residual moisture on vertisols after harvesting cereals or legumes. The production and productivity of chickpea is constrained by several biotic and abiotic factors. Among the biotic constraints, fungal and viral diseases are the major yield limiting factors throughout chickpea producing countries in the world. The major fungal diseases of chickpea include Ascochyta blight (Ascochyta rabiei), fusarium wilt (Fusarium oxysporum $f_{s}$ ciceri) and dry root rot (Rhizoctonia bataticola), while the wet root rot ( $R$. solani) and collar rot (Sclerotium rolfsii) are less important (Beniwal et al. 1992; Seid \& Melkamu 2006). Virus diseases such as the Beet western yellow virus, Bean leaf roll virus, Soybean dwarf virus, the Pea seed-borne mosaic virus and the Chickpea chlorotic stunt virus are economically important in many parts of chickpea growing regions of Ethiopia (Berhanu et al. 2005; Abraham et al. 2009). The incidence of these viral diseases ranges from 0.0 to $22.5 \%$ depending upon seasons and locations (Berhanu et al. 2005).

Wilt/root rot is a soil borne fungal chickpea disease which has been reported to cause losses ranging between 10 and 15\% worldwide (Trapero-Casas \& JimenezDiaz 1985). In extreme cases, the disease can cause up to $100 \%$ crop loss (NavasCortes et al. 2000). In central Ethiopia, Fusarium wilt was reported to cause a yield loss of 30\% (Mengistu \& Negussie 1994). Incidence of between 3 and $70 \%$ (Negussie 1996) and yield loss of 50-80\% (Geletu et al. 1996) were recorded in Ethiopia under farmer's conditions in the 1990s. Since mid-2000s, there have been major initiatives and efforts to scale out chickpea production technologies improved varieties along with their recommended management practices - to the major chickpea growing regions of the country. It remains to be understood how these technologies have impacted some of the major production constraints over the years, especially the wilt/root rot menace. Besides, in some chickpea growing areas, especially in the central parts of Ethiopia such as Southwest Shewa, West Shewa and contiguous zones, survey work on chickpea diseases was last carried out in the late 1990s and this data has not been updated.

Periodic survey of diseases is required to update information on the type, distribution and importance of diseases; to track shifts in disease status following technological interventions or due to ecological and climate changes; and to determine the efficacy of control measures recommended for managing a particular disease. This information is used to prioritise research needs aimed at developing 
efficient disease management technologies and to establish key germplasm screening and testing sites for each of the major diseases. Moreover, survey data are also necessary for projecting fungicide requirements and distribution across different chickpea growing areas in the country. The objective of this survey, therefore, was to determine the current distribution and relative importance of wilt/root rot and stunt diseases of chickpea in Ethiopia.

\section{Materials and methods}

Field surveys were conducted in the third to fourth week of December 2013/2014 and the last week of November to second week of December in 2014/2015 cropping seasons. In 2013/2014 cropping season, zones covered by the survey were West Shewa, Southwest Shewa and North Shewa in Oromiya Regional State and East Gojjam zone in the Amhara Regional State. In the 2014/2015 season, other than those zones surveyed in the 2013/2014 season, the Gurage zone in Southern Nations, Nationalities and Peoples Region was included. The survey routes, soil type and altitude of the surveyed zones are given in Table 1. Chickpea fields were randomly selected at an interval of 5-10 km. Since the area of chickpea grown by a household is about 0.1 ha or less, five $1 \times 1 \mathrm{~m}$ quadrat samples were taken at 2-3 $\mathrm{m}$ interval in cross diagonal line and the crop within the quadrat was inspected for presence of diseased plants. In each quadrat, the total number of plants and the number of diseased plants were counted in situ and recorded. The causative agent of wilt/root rot diseases of chickpea occurs together. Therefore, all dried and partially wilted plants were counted as wilt/root rot affected plants. Stunted chickpea plants that are yellow plants in kabuli type and reddened plants in desi type with leathery leaf, witch-broom crown and brown-coloured phloem when the stem was split were considered as stunt virus affected plants. Where possible ancillary data such as planting time, previous crop and disease management methods were recorded.

Table 1. Chickpea growing niches, soil type and altitude of the surveyed areas.

\begin{tabular}{llrrrrr}
\hline & & \multicolumn{4}{c}{ Soil type (\%) } & Altitude range (m \\
\cline { 3 - 5 } Zone & \multicolumn{1}{c}{ Niche } & Vertisol & Brown & Light soil & Sandy & a.s.I) \\
\hline East Gojjam & Dejen-Awabel & 100.0 & & & & $2404-2465$ \\
& Dejen-Debre Work & 54.5 & 36.4 & 9.1 & & $2402-2581$ \\
& Debre Work-Mota & 0.0 & 50.0 & 50.0 & & $2327-2574$ \\
& Abeya Gorge & 42.9 & 28.6 & 14.3 & & $1738-1947$ \\
& Asteriyo-Adet & 0.0 & 42.9 & 14.3 & 42.9 & $2202-2389$ \\
West Gojjam & Bahirdarzuria & 100.0 & & & & $1665-1944$ \\
Southwest & Jiga-Debre Markos & 75.0 & 25.0 & & & $1810-2220$ \\
Shewa & Buie-Alemgena & 72.7 & 27.3 & & & $2060-2286$ \\
West Shewa & Sebeta-Woliso & 89.5 & 10.5 & & & $2055-2297$ \\
North Shewa & Ambo-Holleta & 87.5 & 12.5 & & & $2140-2435$ \\
Gurage & Debre Tsige-Fitche & 100.0 & & & & $2588-2757$ \\
& Woliso-Wolkite & 100.0 & 0 & & & $1745-2065$ \\
& Butajira-Buie & 80.0 & & 20 & & $1904-2063$ \\
\hline
\end{tabular}




\section{Statistical analysis}

Since most chickpea crop is grown on vertisols and this soil occupies particular niches, the sampled fields within a zone were grouped into one niche when the distance between two successive sample fields along a road was $\leq 20 \mathrm{~km}$. Sampled fields (locations) were nested under each niche and the quadrats in a sample field were considered as replicates. There were five replicates per location. Therefore, a two factor nested design was used to test if the incidence of wilt/root rot disease in chickpea were affected by niche and location. The number of locations within a niche was not equal and thus adjustments for mean squares were made as suggested by Sokal and Rohlf (1995). Then for each location mean incidence of wilt/ root rot diseases along with standard error was calculated.

\section{Results}

\section{Cropping system}

In the 2013/2014 cropping season, out of the 57 sample chickpea fields $18 \%$ were double crops after harvesting different cereal and pulse crops. The preceding pulse crops were haricot bean, faba bean and field pea, while the preceding cereal crops were barley, wheat, maize and to a lesser extent tef (Eragrostis tef). The remaining $82 \%$ of the chickpea fields were planted as sole crops. In the succeeding 2014/2015 season, 110 chickpea fields were surveyed out of which $49.1 \%$ were double cropped. The percentage of chickpea fields that were planted after harvesting maize, barley, wheat and tef were 25.9, 20.4, 14.8 and 5.6\%, respectively. The remaining double cropped chickpea fields were planted after harvesting haricot bean $(22.2 \%)$ and $5.6 \%$ each after faba bean and field pea crops.

In the 2013/2014 season only $7.0 \%$ of the chickpea fields in Southwest and West Shewa zones were sown to improved chickpea varieties. But in East Gojjam zone all chickpea fields were sown to desi type chickpea. In the 2014/2015 season 7.7, $18.8,23.3$ and $9 \%$ of chickpea fields were sown to improved type chickpea in East Gojjam, West Shewa, Southwest Shewa and Gurage zones, respectively. Except in Debre Work-Mota and Asteriyo-Adet niches the soil type was vertisol.

\section{Incidence of wilt/root rot disease in 2013/2014 season}

The difference among niches in wilt/root rot incidence was not significant, whereas the difference among locations within a niche was significant $\left(p<0.05, \mathrm{df}_{1}=50\right.$, $\mathrm{df}_{2}=234$ ). Thus, the contribution of niches and locations within niche to the total variance of wilt/root rot incidence was 4.03 and $35.56 \%$, respectively. The rest $60.41 \%$ of the variance in wilt/root rot incidence was due to within field variations.

\section{East Gojjam zone}

During the $2013 / 2014$ survey $27.3 \%$ of the chickpea field was at flowering and $36.4 \%$ of the crop was either at podding or full podding stage in Dejen-Debre Work 
niche. The mean number of plants per $\mathrm{m}^{2}$ was variable from location to location as was the percentage of wilt/root rot affected plants (Table 2). The mean number of plants per $\mathrm{m}^{2}$ ranged from 19 in Bichena to 52 in Dejen area.

The wilt/root rot disease of chickpea was prevalent in all of the chickpea fields. However, the maximum disease incidence was recorded in Zjenji area where the entire field was wiped out by the disease and the lowest disease incidence was recorded in Debre Work area.

In Debre Work-Mota niche the chickpea crop was at vegetative (11.1\%), flowering (22.2\%), podding (33.3\%) and full podding (33.3\%) stages. Similar to the Dejen-Debre Work niche, there were differences among location in the mean number of plants per $\mathrm{m}^{2}$ and incidence of wilt/root rot diseases (Table 2). The maximum and minimum mean number of plants per $\mathrm{m}^{2}$ was recorded in Ajaja Quamicherq and Bizu-Bizuhan area, respectively. Except in the latter location, wilt/root rot disease was prevalent in the remaining chickpea fields. The chickpea field in Bizu-Bizuhan area was on hill side and the soil was friable light soil.

The Abeya Gorge niche is relatively warm area and as a consequence all the fields were at full podding stage. The wilt/root rot diseases were also prevalent and the percentage of wilt affected plants was in the range of $4-10 \% / \mathrm{m}^{2}$. In the Dejen-Awabel niche the majority (57.1\%) of the chickpea fields were at flowering stage, while 26.8 and $14.3 \%$ of the fields were at podding and full podding stage, respectively. The wilt/root rot disease was also prevalent in all chickpea fields and the percentage of wilt/root rot affected plants was as high as $33 \% / \mathrm{m}^{2}$ in Taba area (Table 2).

\section{Southwest Shewa zone}

In 2013/2014 cropping season only the Sebeta-Woliso niche was assessed for the prevalence of wilt/root rot disease in chickpea. Farmers in this area sow chickpea between mid-September and first week of October. Thus at the time of the survey $14.3 \%$ of the fields were at vegetative stage, $35.7 \%$ were at flowering and the remaining 50\% were at full podding stage. The mean number of plants per $\mathrm{m}^{2}$ was comparable with the mean number of plants per $\mathrm{m}^{2}$ in East Gojjam zone (Tables 2 and 3).With the exception of Awash Bune area where there was no wilt/root rot disease incidence, the remaining chickpea fields were affected by the wilt/root rot diseases (Table 3). Some chickpea fields in Seyoma Genji area, where the highest wilt/root rot disease was recorded, were partially wiped out by this disease.

\section{West Shewa zone}

The frequencies of chickpea fields that were at flowering, podding and full podding stage were equal. The mean number of plants per $\mathrm{m}^{2}$ varied from as few as 14 in Baye Qurbe area to as many as 50 plants in Janjem Legebatu area. The planting time of chickpea in this zone is identical to the planting time of chickpea in Southwest Shewa zone. The wilt/root rot disease was prevalent on $92.9 \%$ of the surveyed chickpea fields; the remaining $7.1 \%$ of the fields were free of wilt/root 


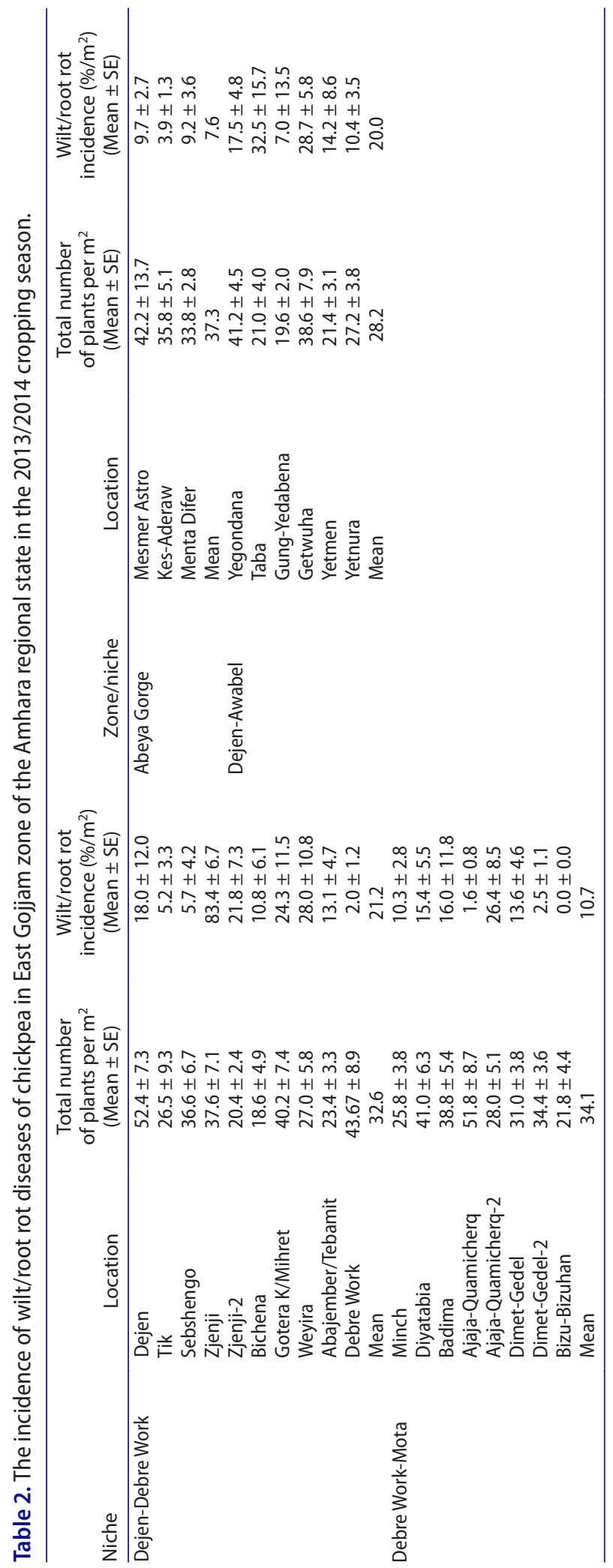




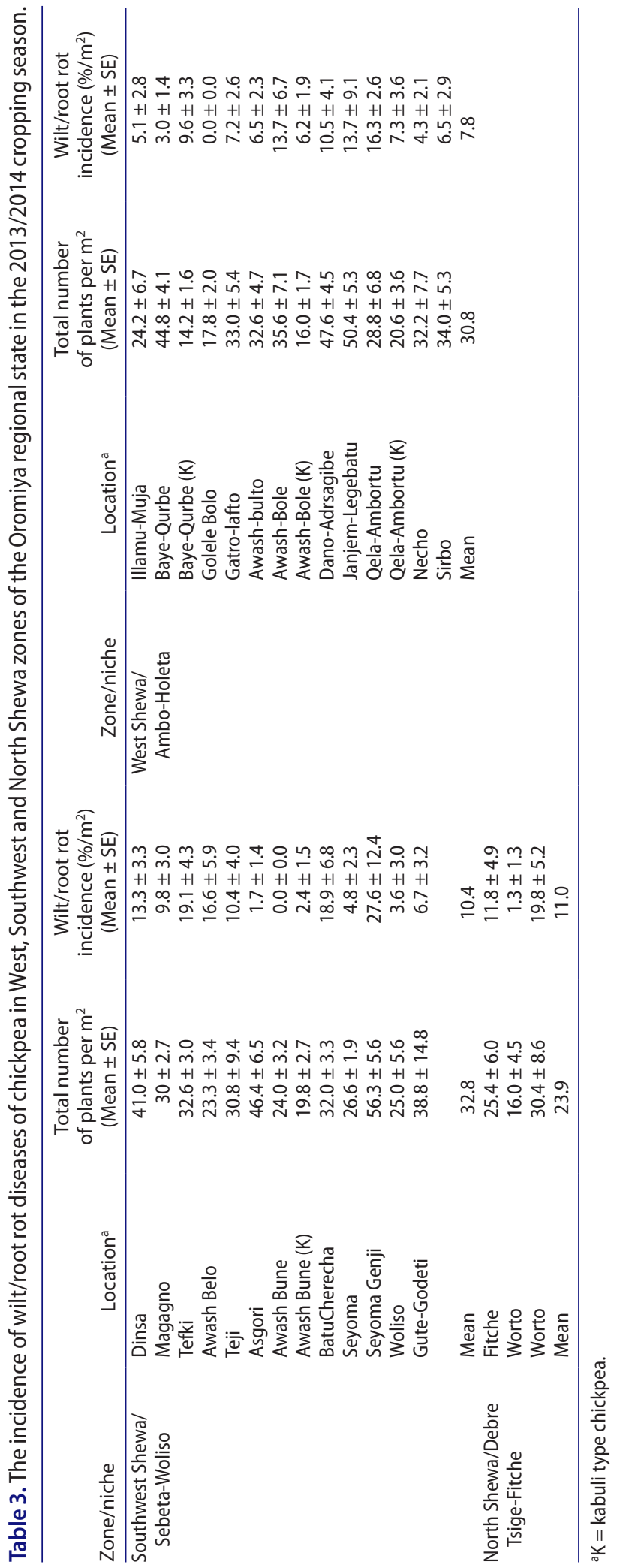


rot diseases (Table 3). The mean maximum number of wilt/root rot affected plants per $\mathrm{m}^{2}$ was five which translates to about $17 \% / \mathrm{m}^{2}$.

\section{North Shewa zone}

Most of the chickpea growing areas of North Shewa zone were inaccessible. Thus, only few fields were surveyed. The surveyed fields were all at full podding stage and had varying level of wilt/root rot incidence level (Table 3). In each chickpea field, patchy areas were completely killed by wilt/root rot diseases. However, in partially affected spots as many as six plants per $\mathrm{m}^{2}$ were killed by the wilt/root rot complex.

\section{Incidence of wilt/root rot disease in 2014/2015 season}

In the $2014 / 2015$ cropping season, there was a significant $\left(p<0.05, \mathrm{df}_{1}=12\right.$, $\left.\mathrm{df}_{2}=109\right)$ difference among niches and locations within niches $\left(p<0.05, \mathrm{df}_{1}=109\right.$, $\left.\mathrm{df}_{2}=444\right)$ in wilt/root rot incidence. Thus niches, locations within niches and within field differences in wilt/root rot incidence accounted for 17.29, 34.74 and $47.97 \%$, respectively, of the total variance.

\section{East Gojjam zone}

Dejen-Debre Work niche chickpea was sown in mid-September and all of the surveyed fields were at flowering stage. The mean number of plants per $\mathrm{m}^{2}$ was between 22 in Ziya and 39 in Debre Work area. Although the level of wilt/root rot disease incidence was variable from location to location, it was prevalent on all fields. The maximum percentage incidence of wilt/root rot disease per $\mathrm{m}^{2}$ was recorded in Telma area (Table 4). This field had double cropped, where chickpea was sown after harvesting faba bean. In the Bichena plain, most chickpea fields had high incidence of wilt/root rot. Consequently, farmers in this area opted to grow grasspea instead of chickpea. Some of them mixed chickpea with grasspea so that the grasspea will replace the dead chickpea plants.

In the Debre Work-Mota niche the majority (55.6\%) of the surveyed fields were at flowering stage, but the remaining 11.1 and $33.3 \%$ of the fields were at vegetative and full podding stages, respectively. The mean number of plants per $\mathrm{m}^{2}$ was relatively greater than chickpea fields in the Dejen-Debre Work niche. The wilt/root rot disease was prevalent in all chickpea fields, although it was extremely low in Bizu Bizuhan area. The chickpea field in the Quamicherq area had the highest percentage of wilt/root rot incidence followed by a chickpea field in Ajaja Quamicherq areas (Table 4). The field in Quamicherq was double cropped with chickpea after harvesting faba bean, while the field in Ajaja Quamicherq area was double cropped with chickpea following barley harvest.

In the Abeya Gorge niche, 57.1 and $42.9 \%$ of the chickpea fields were at flowering and full podding stage, respectively. The mean number of chickpea plants per $\mathrm{m}^{2}$ was in the range of 21 in Astero to 35 in Mine Wuha area. The wilt/root rot disease was prevalent in all chickpea fields and the highest incidence was recorded 


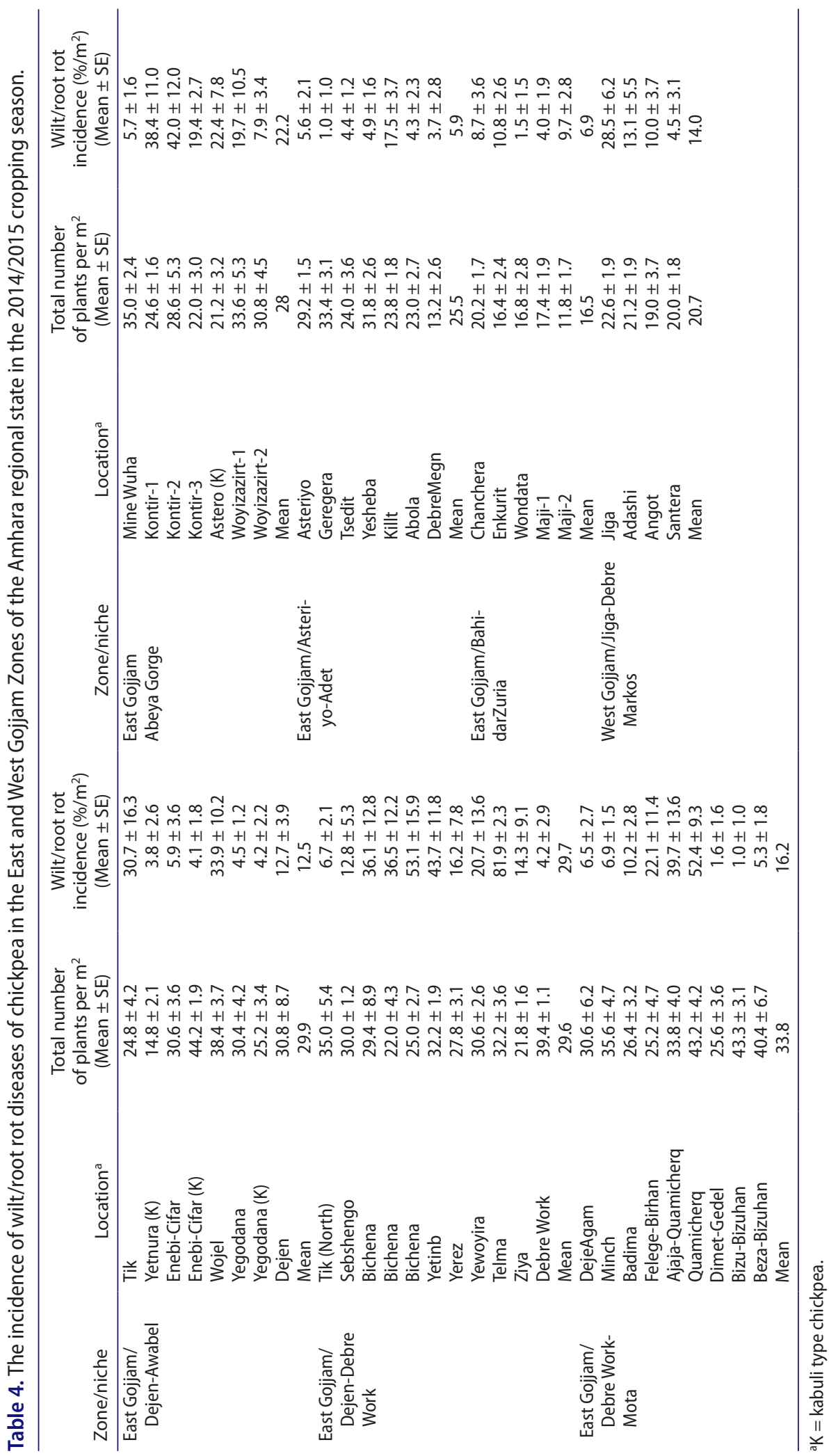


in Kontir areas (Table 4). These fields were double cropped with chickpea after haricot bean, maize or tef crops.

In the Asteriyo-Adet niche about $57.1 \%$ of the chickpea fields were at vegetative stage and the rest $42.9 \%$ were at flowering stage. The chickpea field in Geregea area had the highest mean number of plants per $\mathrm{m}^{2}$, while the lowest number of plants per $\mathrm{m}^{2}$ was recorded in Debre Megn area (Table 4 ). The wilt/root rot disease was recorded in all fields but the incidence was on the average below $6 \%$.

In Bahirdar Zuria niche all the fields were at vegetative stage and the number of plants per $\mathrm{m}^{2}$ was the lowest compared to other surveyed areas (Table 4 ). The wilt/root rot disease was prevalent in all chickpea fields and the incidence varied between $2 \%$ in Wondata area to $11 \%$ in Enkurti area. Most chickpea fields were double crops after haricot bean, maize or tef. In Jiga-Debre Markos niche, the chickpea fields were also double crop and the crop density was more or less similar across locations. However, the level of wilt/root rot incidence was relatively greater in Jiga-Debre Markos niche than the disease level in Bahirdar Zuria. The Jiga area had the highest incidence of wilt/root rot disease but it was the lowest in Santera area (Table 4).

In the Dejen-Awabel niche chickpea fields were at vegetative (62.5\%) and flowering $(37.5 \%)$ stages. The mean number of plants per $\mathrm{m}^{2}$ was variable from location to location and it was highest in Enebi-Cifar area, followed by Wojel and Yegodana areas. The wilt/root disease was prevalent in all fields. However, chickpeas in Wojel and Tik areas had the highest incidence. Thus an average of 13 plants per $\mathrm{m}^{2}$ in Wojel and eight plants per $\mathrm{m}^{2}$ in Tik area, which is equivalent to 34 and $31 \%$, respectively, were killed by wilt/root rot disease (Table 4).

\section{Southwest Shewa zone}

In the Sebeta-Weliso niche because of the extended rainfall most farmers sowed chickpea up to the last week of October. Consequently, about $47.4 \%$ of the chickpea fields were at vegetative stage; had plants germinated at different times or seeds that had not yet germinated. The remaining fields were at flowering (36.8\%), podding (10.5\%) and full podding (5.3\%) stages. Despite this fact fields in Bonge and Gurabaka (sown to desi type chickpea) had as many as 61 and 64 plants per $\mathrm{m}^{2}$, respectively (Table 5 ). The lowest number of plants per $\mathrm{m}^{2}$ was recorded in the latter location where the field was sown to kabuli type chickpea. The wilt/root rot disease was prevalent in $84.2 \%$ of the chickpea fields but in the remaining $15.8 \%$ of the field wilt/root rot killed plants were not found. The Buie-Alem Gena niche was assessed for wilt/root rot disease prevalence only in 2014/2015 season. The fields were at flowering (9.1\%), podding (63.6\%) and full podding (27.3\%) stages. The number of plants per $\mathrm{m}^{2}$, as was the case in other chickpea growing areas, was highly variable and ranges from 14 plants in field sown to kabuli type chickpea in Sedeen to 42 plants in Boneya area. The wilt/root rot disease was prevalent in all chickpea fields (Table 5). In Haro area, where the highest incidence of wilt/root rot disease was found, an average of seven plants per $\mathrm{m}^{2}$ (equivalent to $26 \%$ ) was hit 


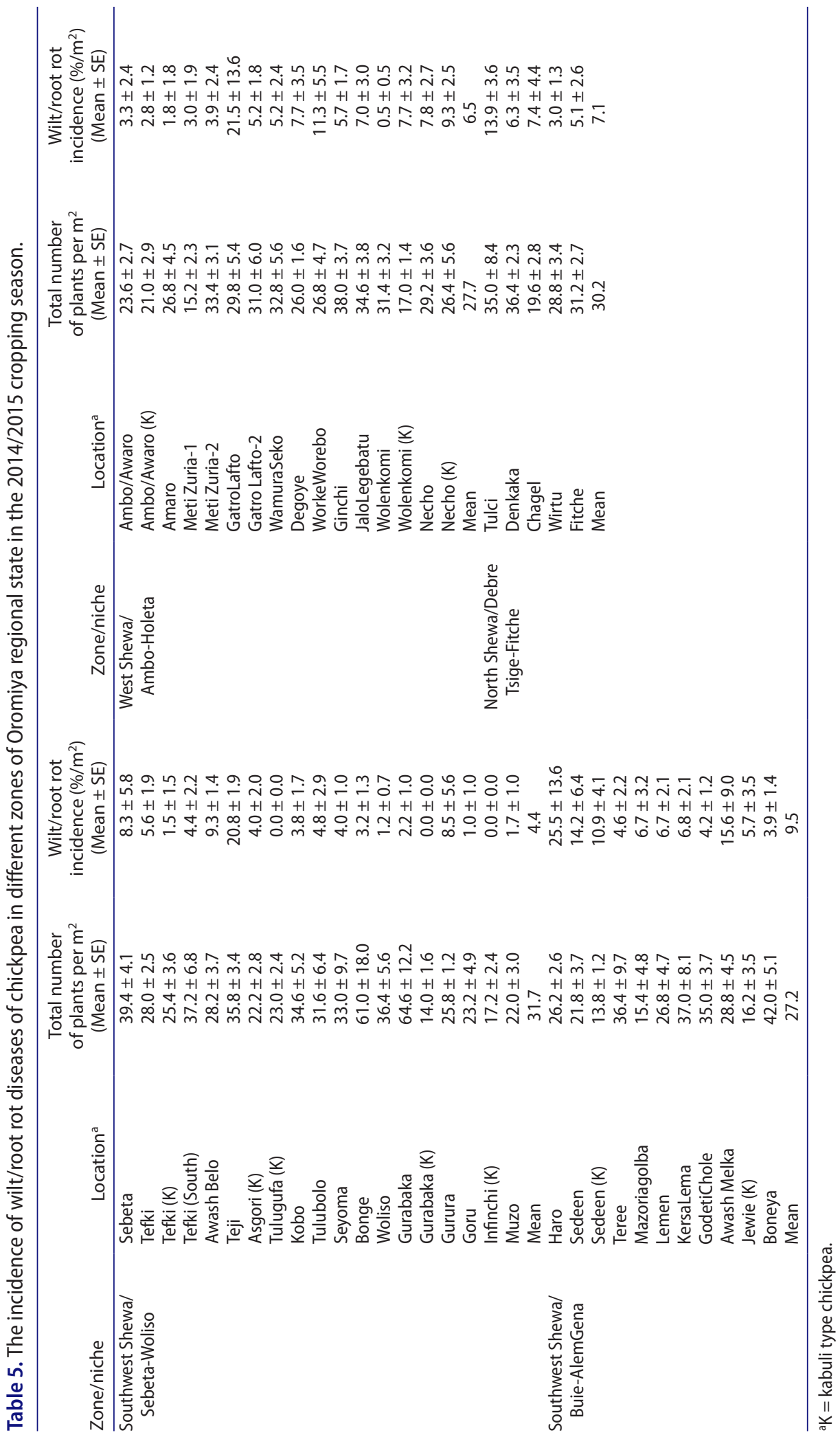


Table 6. The incidence of wilt/root rot disease of chickpea in Gurage zone of SNNP region 2014/2015 cropping season.

\begin{tabular}{llcc}
\hline Zone/niche & \multicolumn{1}{c}{ Location $^{\mathrm{a}}$} & $\begin{array}{c}\text { Total number of plants } \\
\left.\text { per } \mathrm{m}^{2} \text { (Mean } \pm \mathrm{SE}\right)\end{array}$ & $\begin{array}{c}\text { Wilt/root rot incidence } \\
\left(\% / \mathrm{m}^{2}\right)(\text { Mean } \pm \mathrm{SE})\end{array}$ \\
\hline Gurage/Woliso to-Wolkite & Jejeba & $16.6 \pm 5.4$ & $7.6 \pm 4.9$ \\
& Goflele & $17.8 \pm 2.2$ & $16.6 \pm 4.3$ \\
& Hole & $26.2 \pm 3.5$ & $0.0 \pm 0.0$ \\
& Wolkite & $25.8 \pm 1.6$ & $0.0 \pm 0.0$ \\
& Warabeshema (mixed) & $11.4 \pm 1.3$ & $3.5 \pm 2.1$ \\
& Warabeshema (K) & $13.8 \pm 3.2$ & $0.0 \pm 0.0$ \\
Gurage/Butajira-Buie & Mean & 18.6 & 4.6 \\
& Jole-1 & $29.8 \pm 4.6$ & $3.7 \pm 2.3$ \\
& Dileleesa & $22.8 \pm 3.1$ & $4.1 \pm 2.1$ \\
& Negesa-1 & $27.4 \pm 2.9$ & $1.8 \pm 1.1$ \\
& Negesa-2 & $16.4 \pm 1.2$ & $9.5 \pm 4.9$ \\
& Buie & $23.6 \pm 3.5$ & $5.5 \pm 3.4$ \\
& Mean & 24 & 4.9 \\
\hline
\end{tabular}

aK = kabuli type chickpea.

by the disease. On the other hand, in Boneya area where the wilt disease incidence was low only two plants per $\mathrm{m}^{2}$ (about $4 \%$ ) were killed by wilt/root rot disease.

\section{West Shewa zone}

In Ambo-Holeta niche, the stage of the chickpea crop was similar to the SebetaWoliso niche in Southwest Shewa zone. Thus, about half of the surveyed fields were at vegetative stage, $43.7 \%$ at flowering stage and $6.3 \%$ at podding stage. The highest number of chickpea plants per $\mathrm{m}^{2}$ was found in Gichi area where there was an average of 38 plants per $\mathrm{m}^{2}$, whereas the lowest number of plants per $\mathrm{m}^{2}$ was recorded in one of the locations in Meti Zuria (Table 5). The wilt/root rot disease was prevalent in all chickpea fields. However, the incidence of this disease was below $12 \%$.

\section{North Shewa zone}

The chickpea crop was at flowering (40\%) and podding stage (60\%). The mean number of plants ranged from $20 / \mathrm{m}^{2}$ in Chagel to $36 / \mathrm{m}^{2}$ in Denkaka area (Table 5). The wilt/root rot was prevalent in all chickpea fields and as many as five plants per $\mathrm{m}^{2}(\approx 14 \%)$ were recorded in Tulchi area.

\section{Gurage zone}

In the Woliso-Wolkite niche of Gurage zone all the surveyed fields were double cropped either after haricot bean or maize. The crop was only at vegetative stage. The number of chickpea plants per $\mathrm{m}^{2}$ was relatively less than the density of chickpea in other areas (Table 6). The frequency of wilt/root rot disease affected and unaffected fields was equal. The highest wilt/root rot incidence was recorded in Goflele area where about three plants per $\mathrm{m}^{2}(\approx 17 \%)$ were hit by this disease.

In the Butajira-Buie niche, the chickpea crop was either at flowering (60\%) or podding (40\%) stage. Some of the double cropped chickpea fields, which were adjacent to sampled fields, were in poor condition and had very sparsely populated 
plants. The density of chickpea plants per $\mathrm{m}^{2}$ was about 16 in Negasa and about 30 in Jole-1 area. All the surveyed fields were affected by wilt/root rot diseases and the highest incidence was recorded in Negasa area (Table 6).

\section{Discussion}

Regardless of the differences in soil types and cropping patterns, the wilt/root rot disease was prevalent in all the surveyed areas. Surveys conducted in the 1980s (Beniwal et al. 1992), 1990s (Negussie 1996) and 2000s (Merkuz et al. 2011) indicated that wilt/root rot disease of chickpea is widely distributed in major producing regions of the country. Moreover, depending on agroecologies, locations, crop stages and seasons when the surveys were carried out, the respective wilt/ root rot incidence reported by these workers was in the range of $1-41 \%, 3-68 \%$ and $2-62 \%$, respectively. Thus, the incidence and distribution of the wilt/root rot disease found in the present study suggest that the situation has not improved over the years even with aggressive dissemination activities conducted in the 2000s.

The situation raises two questions. First, why is the wilt/root rot disease so widespread throughout the chickpea growing areas? Secondly, why have the prevalence and incidence levels not decreased due to the efforts made during the scaling up of improved chickpea production technologies? A plausible argument here is that water logging is common in the vertisols where chickpea is mostly grown. Vertisols in Ethiopia occur in $0-2 \%$ slope range in the highland plateaus where with high rainfall patterns (Jutzi 1988). This condition results in severe seasonal waterlogging which in turn creates conducive environment for wilt/root rot causative pathogens to thrive and cause the diseases. Water logging has been suggested to breakdown cultivar resistance to Fusarium wilt probably through phenylalanine ammonia lyase enzymes (Midmore 2015).

There is also a possibility that the varieties deployed in the promotional activities lack resistance to one or more of the causative agents of the wilt/root rot complex of diseases. Many of the varieties released in Ethiopia and promoted under various projects have been screen for resistance to Fusarium wilt at a sick plot in Debre Zeit Agricultural Research Centre. As such they are expected to be resistant to common races of Fusarium wilt in Ethiopia. However, the race distribution of the causative agents of wilt/root rot complex of diseases has not been fully characterised in Ethiopia. Up to seven races of Fusarium wilt of chickpea have been described with race 0 in California, Spain and Tunisia, races 1-6 in California, Spain and Morocco (Bull et al. 1991), but it is not known which race is present where in Ethiopia. Without a race by variety differential tests, it may not be accurate to conclude that varieties selected on the sick plot are resistant to all Ethiopian races of the pathogen. High resistance to Rhizoctonia dry root in the field is not common among cultivated chickpea varieties. Wet root rot on the other hand is a minor disease and limited efforts have been made to develop resistance. Hence, even with Fusarium wilt resistant varieties, there are possibilities 
that the drying/wilting reported in the field could be due to root rots rather than Fusarium wilt per se.

The other possibility is that adoption rates of improved varieties with wilt or root rot resistance has been low. As best as could be identified under field conditions in this study, only 7 and $8-23 \%$ of the surveyed fields were found to be under improved chickpea varieties. The majority of the farmers in Ethiopia grow landrace chickpeas, which are susceptible to wilt/root rot diseases (Seid \& Melkamu 2006; Merkuz et al. 2011). Ethiopian landraces are mostly desi type. There are many improved chickpea desi varieties disseminated through various projects, but it is not easy to identify improved vs. landrace desi varieties in the field. Overall, these hypothesised answers require full-fledged study to validate and confirm the main reasons for widespread incidence of wilt/root rot diseases and design sustainable control measures.

There were statistically significant differences in the incidence of wilt/root rot disease incidence among locations within niches, which might be due to the differences in the relative proportion of causative agents of wilt/root rot disease and slope of the land encouraging water logging or transfer of the disease through surface runoff. For instance in the 1994/1995 cropping season more than $50 \%$ of the wilt/root rot disease in chickpea was caused by F. oxysporum f.sp. ciceri, while the $R$. bataticola, S. rolfsii, $R$. solani and F. solani were less prevalent (Negussie 1996). Two years later Negussie et al. (1998) found different proportion of the fungal species from wilt/root rot affected plants sampled from different fields in a location. The other reason related to the causal fungi is probably the presence of physiological races. For instance, under Ethiopian condition Meki et al. (2008) have reported the existence of physiological races of F. oxysporum f.sp. ciceri, which cause different incidence and severity of the disease in chickpea.

Variation in planting time also explains the differences in the incidence of wilt/ root rot disease among locations within a niche. In the 2014/2015 season, for instance, the majority of the fields in Dejen-Awabel niches (63\%), Sebeta-Woliso niche (47\%) and Ambo-Holeta niche (50\%) were late planted as most of them were at vegetative stage at the time of the survey. Farmers in Ethiopia plant chickpea late in the rainy season to escape wilt/root rot diseases that they usually face when they plant chickpea early in the rainy season (Geletu et al. 1994).

The high level of within field variability to the total variance is ascribed to the irregular spatial distribution of inoculums in the field. In the present study, this was reflected in the mean-variance relationship (data not shown). With the exception of those fields where the mean incidence of wilt/root rot was zero, the variances were much greater than the mean incidence indicating that the amount of wilt/root rot incidence was variable from quadrat to quadrat within a field.

Although the degree of wilt/root rot disease incidence found in present study falls within the range of values of wilt/root rot disease incidences reported by earlier workers, it might be different in the actual number of plants affected by the disease. Consequently, comparison of results is impossible as earlier workers have 
not reported the chickpea plant density they found in a given area. For instance, Merkuz et al. (2011) reported 38\% wilt/root rot incidence in Enemay district (Dejen-Debre Work niche in the current study), which may mean 4 or 15 plants if the number of chickpea plants per unit area were 10 or 40 , respectively. Therefore, reporting percentage values along with total number of plants in a unit area and use of consistent name of locations is recommended to have usable historical data.

In East Gojjam zone - except in the Dejen-Awabel niche - the average incidence of wilt/root rot disease incidence increased from 8 to $21 \%$ in the 2013/2014 season to $16-30 \%$ in the 2014/2015 cropping season. But in Dejen-Awabel niche, in East Gojjam zone, in Southwest and West Shewa zones it decreased from 20, 10 and $8 \%$ in the $2013 / 2014$ season to 13,4 and $7 \%$, respectively, in the $2014 / 2015$ season. One of the possible explanations for the season to season difference in the incidence of wilt/root rot disease is the difference between seasons in the amount of rainfall and length of rainy period. The 2014/2015 season had unusually extended rains ending in the third week of October while 2013/2014 season rainfall period terminated early in the first week of September. These variations could affect the prevalence of the wilt/root rot causing organism. Rhizoctonia dry root rot is common in warm dry climates and generally appears during late flowering and podding stages, causing complete drying of the infected plants (Pande et al. 2004). Fusarium wilt too is common in warmer and drier climates and causes seedling or plant death, usually in patches. Wet root rot on the other hand appears at early stages and occurs at high soil moisture levels (30-80\%) and the symptoms on the above-ground plant parts are similar to those of fusarium wilt, particularly the drooping of branches. Depending of pathogen populations in the field and the prevailing temperature and moisture conditions, symptoms associated with wilt root rot complex may appear at varying degrees in the chickpea fields.

Farmers in the surveyed area practice double cropping of chickpea after harvesting cereals (barley, wheat, maize and tef) and pulse crops (faba bean, haricot bean and field pea). Although this practice is excellent practice from economic and resource utilisation point of view, the crop sequence particularly pulse crop after pulse crop favours the prevalence and incidence of wilt/root rot disease of chickpeas. For instance, in Telma where $82 \%$ wilt/root rot incidence was recorded the chickpea crop was double cropped after harvesting faba bean. Therefore, the practice of growing pulse crop after pulse crop should be discouraged.

\section{Conclusion}

The wilt/root rot diseases are prevalent in the major chickpea growing regions of the country. Unlike in other plant diseases incidence and severity of wilt/root rot diseases are equal. Wilted chickpea plants die without producing grain once they are infected with the pathogen. Thus, wilt/root rot diseases cause yield losses by reducing the number of plants in a given area. Besides planting late in the season farmers in the surveyed area did not practice wilt/root rot management methods 
such as the traditional methods of ridge and furrow; drawing shallow drainage furrows at varying distances across the contour and improved management methods (resistant varieties, seed dressing fungicides) or the integration of two or more of these methods. Therefore, wilt/root rot management strategies should be formulated into integrated crop management package and made available to farmers. Moreover, characterising pathogenic variability of the causal organisms of wilt/root rot diseases is also required to identify screening and testing sites so that variety improvement can be targeted to develop resistance to known races.

\section{Acknowledgements}

The authors acknowledge Dr Negussie Tadesse, Asrat Zewudie, Eresi Megersa, Tayu Shewangizaw, Woncha Bejiga and Assefa Kebede for their help during data collation. This study was conducted jointly by Debre Zeit Agricultural Research Center and the International Crops Research Institute for the Semi-Arid Tropics (ICRISAT) as part of the CGIAR Research Program on Grain Legumes (CRP-GL) with financial support availed through ICRISAT.

\section{Disclosure statement}

No potential conflict of interest was reported by the authors.

\section{ORCID}

Chris O. Ojiewo (D) http://orcid.org/0000-0002-2885-9381

\section{References}

Abraham AD, Menzel W, Varrelmann M, Vetten HJ. 2009. Molecular, serological and biological variation among chickpea chlorotic stunt virus isolates from five countries of North Africa and West Asia. Arch Virol. 154:791-799.

Beniwal SPS, Ahmed S, Gorfu D. 1992. Wilt/root rot diseases of chickpea in Ethiopia. Trop Pest Manage. 38:48-51.

Berhanu B, Kumari SG, Kemal A, Yusuf A, Makkouk KM, Mandefro A, Melkamu A, Gelelbelu G, Dereje H. 2005. Survey of viruses affecting legume crops in the Amhara and Oromia regions of Ethiopia. Phytopathol Mediterr. 44:235-246.

Bull CT, Weller DM, Thomashow LS. 1991. Relationship between root colonization and suppression of Gaeumannomyces graminis var. tritici by Pseudomonas fluorescens strain 2-79. Phytopathology. 81:954-959.

[CSA] Central Statistical Agency. 2015. Agricultural sample survey 2014/2015 (2007 E.C.) Report on area and production of major crops. Statistical Bulletin no. 578. Addis Ababa: The Federal Democratic Republic of Ethiopia.

Geletu B, Abebe T, Seifu T. 1994. Effect of sowing date and seeding rate on the yield and other characters of chickpea (Cicer arietinum L). Ethiopian J Agric Sci. 14:7-14.

Geletu B, Million E, Yadeta A. 1996. Improved cultivars and production technology of chickpea in Ethiopia. Debre-Zeit Agricultural Research Center Research Bulletin. No. 2: p. 60.

Jutzi S. 1988. Contributions of vertisols to the national food self-sufficiency: actuals and potentials. Ethiopian J Agric Sci. 10:61-70. 
Meki S, Seid A, Sakhuja PK. 2008. Pathogenic variability in Ethiopian isolates of Fusarium oxysporum f. sp. ciceris and reaction of chickpea improved varieties to the isolates. Int J Pest Manage. 54:143-149.

Mengistu H, Negussie T. 1994. Chickpea and lentil disease research in Ethiopia. In: Asfaw T, Geletu B, Saxena MC, Solh MB, editors. Cool-season food legumes of Ethiopia. Proceedings of the First National Cool-Season Food Legumes Review Conference; 1993 Dec 16-20; Addis Ababa: ICARDA; p. 315-366.

Merkuz A, Sakhuja PK, Chemeda F, Seid A. 2011. Status of chickpea fusarium wilt (Fusarium oxysporumf.sp. ciceris) in northwestern Ethiopia. Arch Phytopathol Plant Prot. 44:1261-1272.

Midmore DJ. 2015. Principles of tropical horticulture. Centre for Agriculture and Bioscience International (CABI), UK. ISBN-13: 978-1780645414, Oxfordshire: University of Reading; p. 450 .

Navas-Cortes JA, Hau B, Jimenez-Diaz R.M. 2000. Yield loss in chickpeas in relation to development of fusarium wilt epidemics. Phytopathology. 90:1269-1278.

Negussie T. 1996. Survey for race situation and causal organisms of wilt/root rot diseases of chickpea and lentil in Ethiopia. Nile valley and Red Sea regional program on cool season food legumes and cereals. Annual report (1994/95). Addis Ababa: EIAR; p. 59-61.

Negussie T, Melkam A, Geletu B. 1998. Survey and identification of the major organisms causing wilt and root-rots and their relative importance in chickpea and lentil in Ethiopia. In: Nile Valley and Red Sea Regional Program on cool-season food legumes and cereals. Annual Report 1996/97, International Center for Agricultural Research in the Dry Areas (ICARDA); ICARDA/NVRSRP/NW-DOC-006. p. 89-90.

Pande S, Krishna Kishore G, Rao Narayan J. (2004). Evaluation of chickpea lines for resistant to dry root rot caused by Rhizoctonia bataticola ICPN. 11: 37-38.

Seid A, Melkamu A. 2006. Chickpea, lentil, grasspea, fenugreek and lupine disease research in Ethiopia. In: Ali, K, Kenneni, G, Ahmed, S, Malhorta, R, Beniwal, S, Makkouk,K, Halila, $\mathrm{MH}$, editors. Food and forage legumes of Ethiopia: progress and prospects. Proceedings of the Workshop on Food and Forage Legume; 2003 Sept 22-26; Addis Ababa: Internation Center for Agricultural Research in the Dry Areas (ICARDA). p. 215-220.

Sokal RR, Rohlf FJ. 1995. Biometry: the principles and practice of statistics in biological research. 3rd ed. New York (NY): W. H. Freeman and Company.

Trapero-Casas A, Jimenez-Diaz RM. 1985. Fungal wilt and root rot diseases of chickpea in Southern Spain. Phytopathology. 75:1146-1151. 